\title{
Sexual Misconduct: What the Qur'an Tells Us about Pre-Marital vs Extra-Marital Sex
}

\section{Qur'anic Verses on Sex Outside Marriage}

This topic is obviously not a women-centric one but applies to men and women equally. I am including it in this book on women's rights in the Qur'an because of egregious practices that primarily target women in today's world and that are falsely said to be religious in nature.

As with other books of ancient scripture, the Qur'an takes a negative and strict view of sex outside marriage. We have touched upon this topic already in Chap. 14, entitled Marriage, such as in verses that insist on not treating household staff and slaves as consorts or concubines but marrying them honourably if they are agreeable $(4: 25,24: 32-3)$.

We have also seen in Chap. 18, entitled Witnesses, how verse 4:16 says that those who commit a sexual indecency but are remorseful must be left alone and not harassed, and that God moreover promises to forgive them:

Women, 4:15-16

As for those of your (pl.) women who commit an indecency (fahisha), call four witnesses against them from among you. Then if they (so) testify, confine them in their houses until death overcomes them or God provides them a way.

And as for the two among you who commit it, penalise them both. But if they repent and make amends, then leave them be. For God is everRelenting, ever-Merciful. 
and

The House of 'Imran (Joaquim, father of Mary), 3:135-136

And when those who commit an indecency (fahisha) or (otherwise) wrong themselves remember God and pray that their sins be forgiven-for who can forgive sins but God?-and do not wilfully persist in what they have done,

The reward of those is forgiveness from their Lord and gardens underneath which rivers flow, where they shall dwell forever. How excellent a wage for those who labour!

Meanwhile elsewhere the Qur'an mentions the obvious: that adultery, i.e. extra-marital sex (zina), is also an indecency (fahisha) (17:32), and that adultery is also forgiven if the perpetrators repent $(25: 68-71)$ :

The Night Journey, 17:32

And do not go near adultery (zina), for it is an indecency (fahisha) and an evil way.

The Criterion, 25:68-71

And those who do not call upon another god alongside God, nor kill the soul that God has made inviolable except rightfully, nor commit adultery (zina) - for whoever does this shall meet recompense

and their punishment on the Day of Resurrection shall be multiplied and they shall dwell therein forever, humiliated,

except whoever repents and does good deeds: for those, God shall replace their evil deeds with good ones, for God is ever-Forgiving, ever-Merciful.

And whoever repents and does good does indeed repent unto God in true repentance.

What the above verses show is that society is to forgive both premarital and extra-marital sex even if four witnesses testify to having witnessed the act, if the guilty parties express remorse and do good, as God Himself will forgive them. Interestingly, all juristic views have always 
maintained that the four witnesses must have observed the act of intercourse itself and not simply behaviour or a situation that implies it. ${ }^{1}$

But the Qur'an takes a harder line on extra-marital sex (zina) than it does on pre-marital sex (sexual fahisha) where unvepentant violators are concerned. It suggests that the unrepentant guilty parties be "flogged" (to be defined below) and not simply confined at home until death or "until God provides a way", i.e. marriage ${ }^{2}$ for the woman, or a commensurate though unspecified penalty, which logic indicates could also involve confinement till death or marriage but which may have historically involved banishment, ${ }^{3}$ for the man:

\section{Light, 24:2-4}

The adulteress and the adulterer [i.e. who commit zina], flog each of them a hundred times, and do not let pity for them overcome you in accordance with God's religion if you believe in God and the Last Day. And let their punishment be witnessed by a group of the believers.

The adulterer shall not marry save an adulteress or polytheistic/idolatrous woman, ${ }^{4}$ and the adulteress-none shall marry her save an adulterer or polytheistic/idolatrous man. For that is forbidden to the believers.

${ }^{1}$ Asad, Muhammad. 2003. The Message of the Qur'an. Bristol, England: The Book Foundation, 595 and Nasr, Seyyed Hossein (editor-in-chief) et al. 2015. The Study Quran: A New Translation and Commentary. New York: HarperCollins Publishers, 868. Curiously, pre-Islamic Arabia is described elsewhere-see Smith, Huston. 2001. Islam: A Concise Introduction. New York: HarperOne, 7-8-as a chaotic place where "Drunken orgies were commonplace", although I have not come across commentary that links this fact to the Qur'anic verses on sexual misconduct.

${ }^{2}$ The majority view is that "until God provides them a way" in 4:15 refers to lawful marriage in the future but stunningly, some commentators actually claim that it refers to the punishment of "flogging" that would later be revealed by the Qur'an to supposedly apply to both witnessed pre-marital and extra-marital sexual misconduct, which I have hopefully shown could not have been the case. See Nasr et al. Ibid., 195.

${ }^{3}$ All commentaries I have seen on sexual misconduct mention banishment as one of several penalties imposed historically for this offence.

${ }^{4}$ While mushrik refers to ascribing partners to God and so can mean polytheism, in the context of the time it also meant idolaters, even if only a single false god or idol was being worshipped. 
As for those who accuse chaste women ${ }^{5}$ (mubssanat) but do not produce four witnesses, then flog them eighty times and do not accept a testimony from them ever (again). Those-they are the immoral ones.

Now with regard to how the Prophet understood and instructed that the Qur'anic penalty of "flogging” be administered for proven adultery or false accusations of such, it is interesting to learn from classical jurists that the purpose of the "flogging" appears to have been to somewhat shame rather than to cause physical damage or pain: besides the Qur'anic instruction that the "flogging" occur before a limited public, commentator descriptions spoke of the requirement that a respected member of the community (and not just anybody) administer the lashes while not raising the arm above shoulder level nor using anything too hard so as not to break the skin, with the person being lashed remaining in a standing position and unbound. ${ }^{6}$ Moreover, reports indicate that among the instruments used for "flogging" at the time were items of clothing and footwear, "a light sandal or even the hem of a garment", ${ }^{7}$ which supports this understanding of the goal having been limited public shaming rather than corporal punishment.

I thought I was done with defining what "flogging" actually meant (as explained above) when some days later, while in meditation, a new insight suddenly popped into my head. Throughout the process of writing this book, sitting in silent meditation to invoke God before every writing session has been a must, one without which the task ahead always seemed too daunting to pursue. These sessions would literally give me the strength to carry on, to tackle however complex a topic lay ahead. And so it was in one such session, when I was no longer thinking of the "flogging" verse at all, that the following came to mind: of course they "flogged" with

\footnotetext{
${ }^{5}$ See Chap. 18, footnote 4 . As mentioned there, I am among those who understand the word mubsanat to refer to all chaste women and not only faithful married women, because the subject of 24:4 and subsequent verses is falsely accusing innocent women of sexual misconduct and the penalty incurred by the false accusers regardless of the marital status of the woman.

${ }^{6}$ Nasr et al. Op. Cit., 868.

${ }^{7}$ Kamali, Mohammad Hashim. 2019. Crime and Punishment in Islamic Law: A Fresh Interpretation. New York: Oxford University Press, 167-168. Also, some reports state that the person administering the "flogging" must not raise his arm above his elbow, i.e. even lower than the shoulder.

${ }^{8}$ Smith, Huston. Op. Cit., 67. I have borrowed the quotation marks around the term-as in "flogging" - from this same reference, which seems appropriate given that the act was not intended to deliver pain or physical harm as the term otherwise implies.
} 
harmless instruments such as clothing and in order to shame, because how could God have otherwise prescribed the same number of lashes for women as for men, given our physical differences?

Needless to say, from a twenty-first-century perspective even this "gentle" form of "flogging" that is merely designed to shame the guilty to a limited extent rather than physically hurt them seems excessively humiliating and intrusive, given that personal relations today are viewed as a private rather than a public affair. But in the seventh century and within the context of the time, this would no doubt have been seen differently, falling broadly in line with societal expectations. Indeed in several hadith reports we are told that people came up to the Prophet to confess their sexual exploits voluntarily, ${ }^{9}$ which reinforces, to my mind, that they did not expect to be physically tortured by being flogged mercilessly. As a surprising numerous of religious leaders and scholars have pointed out, Qur'anic penalties for sexual misbehaviour were made for a society where marriage was made easy, sexual provocations were virtually absent and piety was the norm, a far cry from the world we live in today. ${ }^{10}$

Now that we have looked at the verses addressing what the Qur'an considers illicit sex, you are likely to be asking yourself three questions.

First, why do we never hear of the relatively "light" punishment of confining guilty women at home (which, incidentally, implies that it was not customary for women to remain house-bound) until something gives, nor of a commensurate or similar "light" penalty for men (4:15-16)?

Second, whatever happened to the often-heard claim that the Qur'an instructs that the guilty parties be stoned to death?

Third, why are women mentioned first, before men, in verses 4:15 and 24:2, when the linguistic custom is the other way round as evidenced throughout the Qur'an itself?

The answers to these questions shed light, respectively, on juristic tendencies, the conflation of culture and religion, and the relentless advocacy of the Qur'an on behalf of women, as will be shown below.

\footnotetext{
${ }^{9}$ Nasr et al. Op. Cit., 865-7.

${ }^{10}$ See Kamali, Mohammad Hashim. 1995. Punishment in Islamic Law: An Enquiry into the Hudud Bill of Kelantan. Kuala Lumpur: Institut Kajian Dasar, 111-115.
} 


\section{The Pushback of Jurists on "Light” Penalties for Sexual Misconduct: But Some Verses in the Qur'an Cancel Out Others!}

It is a shocking thing to me that so much of our juristic commentary claims that some verses in the Qur'an were abrogated-i.e. cancelled out or replaced-by other verses within the Qur'an itself.

Every believing Muslim maintains that every word in the Qur'an is sacred, yet our own jurists often maintain that some verses should be totally ignored, as if they were not there. If so, why were these verses kept as a part of the Qur'an in the first place? Or are they implying that God made several mistakes on several topics, later correcting Himself, but it was all left in because both mistakes and corrections belong to Him?

Or is it that the archangel Gabriel's memory faltered and caused him to initially deliver the wrong message to the Prophet on a number of topics, triggering the need for a "replacement" verse?

Outrageous as this sounds, this is precisely what we are effectively asked to accept with regard to many a topic in the Qur'an. Many jurists claim that the "lighter" punishments of confinement for the woman and a commensurate but unspecified penalty for the man (perhaps banishment $^{11}$ ) in verses 4:15-16 were cancelled out by the stronger punishment of "flogging" for both parties in verse 24:2, in the process collapsing the distinction between pre-marital and extra-marital sex in these verses, respectively. The rare expert voice that has rejected abrogation on principle has at times also conflated the two concepts, ${ }^{12}$ treating all fornication the same. Here is why, to my mind, neither logic holds:

- Those who subscribe to abrogation (naskh), i.e. the idea of one verse replacing another seem to overlook verses 25:68-71 shown above: there, adultery (zina) is listed as one of the great sins alongside no less than a) polytheism and b) unjustifiably taking a life, so how could the penalty for it have ever been as light as 4:15's prescription of, effectively, mere "house-arrest" or something commensurate?

- Some scholars who reject all notions of verses abrogating one another but still miss the distinction between pre-marital and extra-marital sex in the Qur'an do so because they do not take fahisha in 4:15 to refer to sexual indecency to begin with: ${ }^{13}$ in principle fahisha on its

\footnotetext{
${ }^{11}$ See footnote 3 .

${ }^{12}$ Asad, Muhammad. Op. Cit., 121.

${ }^{13}$ Ibid.
} 
own is a general and undefined indecency, but how can $4: 15$ be decoupled from the very next verse $4: 16$, where reference is made to "two" guilty people?

In any case, the consequence of embracing the abrogation of one verse by another is that jurists now had to also maintain that there is no practical distinction between a sexual fahisha or indecency and zina, adultery, since the issue is not taken up elsewhere in the Qur'an-contrary to the popular misperception that the Qur'an positively dwells on sexual matters. I find this extraordinary, not least because I am certain that no one asked directly could possibly maintain that there is moral equivalence between the two acts, whether from a religious or social point of view.

So where does this bizarre notion that some verses in the Qur'an were abrogated or cancelled out by others come from? ${ }^{14}$ Not surprisingly, it comes from assigning a specific meaning to a particular word in a couple of particular verses $(2: 106$ and 16:101), a word that is not even a verb but a noun, and which can mean several related things depending on how it is used: aya.

At its most specific, aya is a verse in the Qur'an. At its broadest, it is a divine sign or message.

The Cow, 2:105-6

Neither the disbelievers among the People of the Book nor the polytheists/idolaters wish that any good be sent down to you (pl.) from your Lord. But God singles out for His mercy whom He will, for God is of great bounty.

$\checkmark \quad$ No sign (aya) do We efface or cause to be forgotten but We bring forth something better or similar. Did you not know that God is powerful over all things?

which is reminiscent of verses 43:46-48 about Moses showing Pharaoh greater and greater signs (ayas) yet which is usually translated (and interpreted even in Arabic) as follows, which clearly impacts the meaning in a very direct and serious way:

$\times$ No verse do we abrogate or cause to be forgotten...

14 “...there does not exist a single reliable Tradition [ hadith] to the effect that the Prophet ever declared a verse of the Qur'an to have been 'abrogated' ". See Asad, Muhammad. Op. Cit., 31. 
and which is occasionally also translated as follows, which unfortunately encourages the viewing of earlier religions as no longer valid:

$\times$ No revelation do we abrogate or cause to be forgotten...

The context of the first verse 2:105 shown above makes clear that the word aya in the subsequent verse 2:106 cannot possibly be referring to a specific verse in the Qur'an but rather to a different kind of communication from God. It must be pointed out that God here only criticises those among the People of the Book who did not like that a new prophet had come to another people, and does not condemn all those to whom He had previously sent His scripture, given His frequent affirmation throughout the Qur'an of the legitimacy of each one of these, His prior religions, along with their books and prophets.

Similarly:

The Bees, 16:101-2

And when We exchange one sign ( $a y a)$ for another-and God knows best what He sends down - they say: you (Muhammad) are inventing! But most of them do not know.

Say: the Holy Spirit has brought it down from your Lord with the truth, to strengthen those who believe and as a guidance and good tidings to those who surrender (to God).

In the above, again the context makes clear that God is not speaking here of aya as a specific verse of the Qur'an cancelling out another, but of a different type of divine communication that can stand in the same place as another, because they both come from the same divine source, the Holy Spirit.

\section{The Pushback of Culture on the Qur'an Itself: Stone to Death, Kill for Honour or Flog WITH ABANDON}

If the Qur'an speaks of confinement and something commensurate as penalties for unrepentant women and men for pre-marital sex that is witnessed directly by four people, and of "flogging" for extra-marital sex that is also so witnessed, why do we hear so much about stoning?

There is not a single mention in the Qur'an of stoning as a penalty for anything. 
On the other hand, the hadith compilations contain numerous-albeit wildly conflicting, confusing and even bizarre reports ${ }^{15}$ - claiming that Muhammad as Prophet and head of state had overseen stoning for fornication (these reports do not make a clear distinction between the premarital and extra-marital nature of the sexual misconduct in question).

I ask the reader this: Is it remotely conceivable that the Prophet would have defied God's command and ordered stoning to death, rather than "flogging" (to shame), in a worst-case scenario of unrepentant sinners who had been witnessed in the coital act by four people?

This is the same logic as what we discussed earlier in Chap. 14's section "Muhammad's Marriages": Is it remotely conceivable that the Prophet would have defied God's command and taken Mariya as a concubine, or remained unmarried to her, once verses prohibiting unmarried sex with one's servants and slaves $(4: 25,24: 32-33)$ had been revealed?

Moreover, do we care at all that the Prophet's understanding of the spirit of the Qur'an induced him, according to one report, to offer an adulterous confessor three opportunities to withdraw his confession? ${ }^{16}$

Stoning may have been the customary pre-Qur'anic penalty for sexual impropriety, just as taking concubines from among one's domestic staff and slaves was. Indeed there is evidence that these were indeed the norms of the time and place, at least among some communities. But to suggest that the Prophet would have implemented pre-Qur'anic rules on a given issue after the Qur'an had specified its own rules on the same issue is simply not credible, and indeed outrageous from any believer's perspective.

In addition, some scholars have pointed out that since the Qur'an also mentions that the penalty for an enslaved woman should be halved $(4: 25)$ while the same for a wife of the Prophet should be doubled (33:30), then stoning can never have been a Qur'anic prescription: ${ }^{17}$ how can stoning to death be halved or doubled? A hundred "lashes", on the other hand, can be.

In any case and as already discussed above, the penalty of "flogging" unrepentant women or men for witnessed (by four people) adultery appears to have been a symbolic one designed to shame, and most contemporary religious leaders agree with scholars that it has not been an appropriate penalty for a long time given changing social environments. ${ }^{18}$

\footnotetext{
${ }^{15}$ See Nasr et al. Op. Cit., 865-868.

${ }^{16}$ Ibid., 865 and Lang, Jeffrey. 1995. Struggling to Surrender: Some Impressions from an American Convert to Islam. Maryland: Amana Publications, 116-117.

${ }^{17}$ Nasr et al. Op. Cit., 867.

${ }^{18}$ Kamali, Mohammad Hashim. Op. Cit. (1995), 111-115.
} 
How some communities here and there diverge from all the above to advocating no less than murdering a daughter, sister, wife or other, usually female, relative for even the suspicion of having had unmarried sex defies all Qur'anic reason and moral proportionality. To call such murders "honour killing"-supposedly to salvage the honour of the family whose member committed such an act-is to make a mockery of justice as it places the full burden of a family's "honour" on its most disempowered members, its girls and women.

\section{Qur'anic Advocacy for Women in Response to Malicious Accusations}

Lastly, why are women mentioned first, before men, in verses 4:15 and $24: 2$, when the linguistic custom is the other way round as evidenced throughout the Qur'an itself?

As I pondered this question in meditation, asking God to please help me understand "why" because it was so very unusual and I had not seen any commentary on this, the answer suddenly came to me: because the Qur'an was responding to an actual situation and wanted to first confirm such a sinning woman's guilt before a) pointing out that the man would be equally guilty, b) opening the door to forgiveness of both by opening the door to repentance, and c) threatening those who go around accusing women of adultery with their own punishment if they turn out to have slandered the innocent. In other words, the entire flow of the argument is in preparation for advocacy on behalf of accused women.

Here is how the meaning of verses 4:15 and 24:2 flows when accompanied by the verses immediately after each of them:

- Single women who commit a sexual indecency and are witnessed in the act by four people are to be confined to their homes until something gives, death or marriage (4:15)

- But single men who commit a sexual indecency are also guilty and must also be punished (4:16)

and

- An unfaithful married woman and an unfaithful married man are to be "flogged" equally, and before a small public, i.e. to achieve the shaming result $(24: 2)$ 
- An unfaithful married man can only marry an unfaithful married woman and vice versa in future, reinforcing the shame on both $(24: 3)$

- While those who accuse chaste women are themselves to be "flogged", for they are the immoral ones! (24:4)

- Recall, moreover, that the soon-to-follow verses 24:11-26 were in response to the slandering of the Prophet's wife, Aisha, over alleged infidelity committed with another $\operatorname{man}^{19}$

Surely the above shows that the intention of the Qur'an in these verses, which are often quoted in isolation of one another, is nothing short of advocacy on behalf of women in cases of sexual accusations. That God considers such accusations distasteful, to say the least, is self-evident.

\section{Extraordinary hadith on Illicit Sex That We Do Not Hear About}

I came across a couple of thought-provoking and very telling hadiths in a good book on the subject that I would like to share. The writer's commentary surrounding them is also informative so I include some of it below:

...Aisha is reported to have said in response to a man who asked her about the character of God's Messenger: 'The Prophet's character was that of the Qur'an.'

I was [also] guided by these opening words of a talk entitled The Mercifulness of the Messenger of God by the late Martin Lings, 'The mercifulness of Sayyiduna [our lord] Muhammad is affirmed by the Qur'anic verse We sent thee not save as a mercy to the worlds.'

$\ldots$

Abu Hurayrah ${ }^{20}$ reported that the Messenger of God said, 'Forgiveness was granted to a prostitute who came upon a dog panting and almost dead from thirst at the mouth of a well. She took off her shoe, tied it with her head-covering, and drew some water for it. On that account she was for-

\footnotetext{
${ }^{19}$ Ibid., 870.
}

${ }^{20}$ That such a report is attributed to Abu Hurayra is in itself telling, as while he was the most prolific hadith transmitter, he was known to not be the most women-friendly, to put it mildly, with some of the most egregious hadiths on women attributed to him (whether correctly or not), and reports that both Aisha and Omar had clashed with him over some of his demeaning reports. See Chap. 3, footnote 24 . 
given.' He was asked if people received a reward for what they did for animals, and he replied, 'A reward is given in connection with every living creature.' (Bukhari)

But the one which led to the most exhaustive reflection and ultimately helped me to move closer to an understanding of the depth of the Prophet's humanity was this one:

Ibn Abbas reported that a man came to the Prophet complaining, 'My wife rejects no one who lays a hand on her!' The Prophet told him, 'Divorce her.' But the man told him, 'I really love her.' So the Prophet said to him, 'Then, hold on to her.' (Abu Dawud [aka al-Sijistani]) $)^{21}$

I am certain that most readers will be as surprised by the above as I was initially. But on further reflection I realised that the Prophet here was in fact not only giving life to the spirit of the Qur'an, but literally carrying out its instruction. Besides the clear evidence of the Prophet's compassion for the wronged husband, the above is also instructive in that his reaction was not to move to judge and punish the wayward wife: rather, the Prophet chooses to advise either (honourable) separation per the Qur'an or marital reconciliation (despite the wife's repeated infidelity), in accordance with the spirit and indeed letter of a verse specifically addressing infidelity (4:35), which we will take a close look at in the next chapter.

${ }^{21}$ From the introduction by Jeremy Henzell-Thomas to le Gai Eaton, Charles. 2008. The Book of Hadith: Sayings of the Prophet Muhammad, from the Mishkat al-Masabih. Watsonville, California; Bristol, England: The Book Foundation, xxv-xxvi. As he also points out in the introduction in xxviii-xxix, the hadith on forgiveness of the prostitute is reminiscent of the famous incident in the Gospel of St John 8:7 in which the Pharisees bring a woman charged with adultery to Jesus and he replies: 'He that is without sin among you, let him cast the first stone at her', and then says to the woman: 'Neither do I condemn thee: go and sin no more.' 
Open Access This chapter is licensed under the terms of the Creative Commons Attribution 4.0 International License (http://creativecommons.org/licenses/ by $/ 4.0 /$ ), which permits use, sharing, adaptation, distribution and reproduction in any medium or format, as long as you give appropriate credit to the original author(s) and the source, provide a link to the Creative Commons licence and indicate if changes were made.

The images or other third party material in this chapter are included in the chapter's Creative Commons licence, unless indicated otherwise in a credit line to the material. If material is not included in the chapter's Creative Commons licence and your intended use is not permitted by statutory regulation or exceeds the permitted use, you will need to obtain permission directly from the copyright holder. 